\title{
Effects of Hedging Foreign Exchange Risk on Financial Performance of Non-Banking Companies Listed at the Nairobi Securities Exchange
}

\author{
Onesmus Mutunga Nzioka \\ PhD Candidate, Tutorial Fellow, University of Nairobi, School of Business, \\ Department of Finance \& Accounting \\ Faith M. Maseki \\ Research Consultant
}

doi: 10.19044/esj.2017.v13n10p402 URL:http://dx.doi.org/10.19044/esj.2017.v13n10p402

\section{Abstract}

The general objective of this study was to establish the effects of hedging foreign exchange risk on financial performance of non-banking companies listed at the Nairobi securities exchange. A descriptive research design was adopted on the target population of 49 non-banking firms listed at the NSE. Primary data collected using a questionnaire was used containing both open and close ended questions. Data was analyzed using SPSS to generate descriptive statistics such as percentages, frequency distribution, measures of central tendencies (mean) and the data was presented in tables. The study conducted multiple regression analysis to establish the extent to which the hedging techniques affected firm's performance. The results showed that, taking all factors into account (internal hedging techniques, external hedging technique, inflation and interest rates) performance of nonfinancial firms would be 0.564 . The findings presented further indicated that internal hedging had the greatest effect on the firm performance $(\beta=0.551)$, Inflation $(\beta=0.322)$, External hedging $(\beta=0.133$ while interest rate $(\beta=$ 0.024 ) had the least effect to the firms performance. However, all the variables were significant $(\mathrm{p}<0.05)$. Hedging techniques affected firm's performance i.e. profitability, sales revenue and the cash flow and liquidity position of the firm. The internal techniques were more effective on the performance than the external techniques. The four independent variables studied accounted for $75.5 \%$ of the variations in non-banking firms' performance as represented by the adjusted $\mathrm{R}^{2}$. This therefore means the four variables contribute to $75.5 \%$ of performance, while other factors not studied in this research contributes $24.5 \%$. The study recommends that, firms develop a robust foreign exchange risk management framework which clearly shows its currency risk assessment procedure and implementation of 
currency risk management strategies. It also recommends that the various aspects of firm's financial performance be taken into consideration before adopting a particular technique to hedge to protect cash flow, liquidity, profitability and sales revenue.

Keywords: Hedging, Firm Performance, management framework, currency risk , Profitability, Cash flow, Liquidity

\section{INTRODUCTION}

Foreign Exchange Risk is defined as an exposure of an institution/ firm to the possible impact of fluctuations in foreign exchange rates. According to Armitage, Wold \& Weissle (2002), foreign exchange risk is the danger that profits would be affected if foreign exchange rates change. Shapiro (1996) states that there are three types of foreign exchange rate risks that are faced by companies namely; translation or accounting risk, transaction risk, and economic risk. Translation risk in essence is balance sheet exchange rate risk comes up during the preparation of financial accounts in the value recognized in the parent company's financial statements. Essentially, translation risk is the effect exchange rates have on the figures publicized on the parent company's consolidated financial statements. Thus, while income statements are typically translated at the average exchange rate over the period, balance sheet disclosure of overseas subsidiaries are often translated at the current exchange rate at the time of consolidation.

The operating environment for businesses has become very volatile following increased globalization and internationalization of firms. Together with this, the business environment in Kenya has witnessed high variation in the foreign exchange rate over the recent past as the Kenya shilling depreciates against the widely used United States Dollar. Since majority of the firms either source their inputs or sale their output internationally, they have been affected by the fluctuation in exchange rates calling on them to implement necessary measures to manage the foreign exchange risk.

Hedging has conventionally been defined as a tactic for reducing the risk in upholding a market position while speculation refers to taking a position in the way the markets would shift. Nowadays, hedging and speculation strategies, together with derivatives, are versatile tools or methods that enable companies to administer risk more efficiently. A range of hedging techniques is accessible for managing currency risk. These methods may be classified under two clusters: internal techniques are those that are meant at reducing or averting an exposed position from occurring and external techniques are usually contractual measures expected to 
minimize exchange losses that may arise from an existing exposure (Giddy \& Dufey, 2012).

Performance may be defined as an indication of the means in which the resources of a company (bank) are used in the form which enables it to achieve its objectives. According to Herman's (2007), financial performance is the application of financial indicators to quantify the level of objective achievement, contribution to making available monetary resources and support of the bank with investment prospects. Rutagi (1997) defines financial performance as how well an organization is achieving financial objectives. Other scholars describe performance of the organization as the degree to which an organization can accomplish its projected outcome (Namisi, 2002).

\section{Statement of the Problem}

In late 2008, international markets were grossly affected by a sharp and unexpected spike in foreign exchange instability. The global financial crisis caused many firms to revert to existing risk management strategies or formulate new ones. The use of foreign currency derivatives was being reassessed by companies trying to efficiently manage the exaggerated raise in currency risk associated to the global financial crisis (Kirschner, 2009).

The Kenyan security market in regard to spurring new financial innovations remains relatively poor despite being ranked the fourth best in Africa (Mwangi, 2001) The Kenyan economy is becoming more and more open with international trading constantly increasing and as a result Kenyan firms become more exposed to foreign exchange rate fluctuations. The relative price changes affect the firms' competitive market position, leading to changes in cash flows and ultimately, in firms performance (Noor \&Abdalla, 2014).

Even though studies have been conducted on the exchange rate regimes and the implications for macroeconomic management as well as managing foreign exchange risk (Abor, 2005), very little has been done on the study of the firm exposure to exchange risk in Kenya. It is in this context that, this study proposes to answer the question; what are the effects of hedging foreign exchange risk on the financial performance of non-banking listed companies?

\section{Research Objective}

The general objective of this study was to establish the effects of hedging foreign exchange risk on the financial performance of non-banking companies listed at the Nairobi securities exchange 


\section{Specific Objectives}

i. To determine the hedging techniques used to manage foreign exchange risk at the NSE

ii. To establish the effect of hedging foreign exchange rate risk management on financial performance of the NSE.

\section{Literature Review}

Several studies have been done on effects of hedging in risk management and the financial performance of selected listed companies. For instance, Broccardo, Mazzuca and Yaldiz (2013) conducted an empirical investigation on Italian banks on the use and motivations for credit derivatives. The findings seemed not to support the hedging theory in general. From conclusions of the separate estimates for small/large banks and for listed/unlisted banks show that the likelihood of using CD differs when different subsamples are measured, and that the outcome for larger and listed banks tend to substantiate the results of the main regressions on the whole sample.

Allayannis and Ofek (2000) divulge that exporters favor the use of foreign currency derivatives to foreign currency debt when hedging their operations. They use panel data, with a time period of 5 years (1990-1995), which gives a more accurate result as the longer time period accounts for seasonal effects. The advantage of derivatives is that they have a prearranged cost and are available to all companies where as foreign debt is restricted only for large firms. Forwards are recommended for firm obligations whereas options may be ideal for uncertain foreign currency denominated future cash flows. While hedging doubtful exposures from expected transactions, forwards are the favored tools as the uncertainty will be taken into account by adjusting the hedge ratio with forwards. The most frequently used derivative contract to hedge transaction is the currency forward contract.

Shaofang and Matej (2014) examined the use of Financial Derivatives and Risks of U.S. Bank Holding Companies. The study looked at the impact of financial derivatives on systematic risk of publicly listed U.S. bank holding companies (BHCs) from 1997 to 2012. The empirical investigation employed a two-stage time series cross-section regression model to determine the relationship between systematic risk and the use of financial derivatives. They found that, the use of financial derivatives is considerably and positively related to BHCs' systematic risk exposures. Higher use of interest rate derivatives, exchange rate derivatives, and credit derivatives corresponds to bigger systematic interest rate risk, exchange rate risk, and credit risk. The positive connection between derivatives and risks continues for derivatives for trading as well as for derivatives for hedging. 
This study was conducted in a different macro-economic setting from those in Kenya hence limiting their application in the current study context.

Henschel and Kothari (2001) conducted an empirical study to establish the degree to which firms use derivatives to reduce overall stock return unpredictability. They defined hedging as risk management technique that lessens returns instability and speculation as a tool that increases return volatility. Sample data was obtained from 425 large US corporations both financial and non-financial companies. The sample comprised of a section of 200 largest industrial non-financial corporations, 25 largest retailers, 25 largest transportation companies, 25 largest utilities, 50 largest diversified financial firms excluding insurance companies and 50 largest commercial banks in all of USA. These firms were sampled based on the ranking of highest sales in 1987 as published in April 25, 1988 issue of the fortune magazine. The findings contradict the premise that firms use derivatives to speculate on large exposures. They also found out that there was no apparent decrease in the firms' overall risk exposure as a result of using derivatives to hedge. They therefore concluded that firms use derivatives to reduce the risk exposure associated with short term contracts. The current study presents the premise that firms use derivatives to speculate on large exposures

Murungi, Murage and Wanjau (2014) examined the challenges facing non-financial firms in hedging financial risks via derivatives. The research observed that with the development in technology and accompanying information age and globalization, firms are progressively more exposed to financial risks, thus pose a threat to their financial performance even leading ultimate collapse. Innovation has led to innovative ways of hedging against financial risks through derivatives. The data obtained was subjected to descriptive and inferential statistical analysis. Descriptive analysis implicated the employment of frequencies in their absolute and relative forms (proportions), mean and standard deviation were also used. The research came to the conclusion that nonfinancial corporations do not use derivatives due to managerial cynicism, imperfect derivative market microstructure, in addition lack of knowledge on derivative use and how to account for it. The study recommended introduction of edification programs on derivatives and their use to firm's managers and that firms should develop hedging strategies so as act as the blueprint in hedging financial risks. This study did not consider hedging practices and exchange risk exposure.

Runo (2013) examined the relationship linking foreign exchange risk to profitability of oil companies listed in the NSE Using correlation and regression analysis, research results indicated that the foreign exchange risk greatly influences the profits reported by these oil companies. Foreign exchange risk as measured by the foreign exchange gain/loss reported by these companies was found to carry more weight in predicting the 
profitability of these two companies with a correlation coefficient of 95\%. It was recommended that the firm ought to build up a robust foreign exchange risk management structure which evidently shows their currency risk evaluation process and realization of currency risk management strategies.

Ngugi, Njagi and Kimani (2013) examined factors influencing development of financial derivatives markets: a survey of listed companies in Kenya. The data was scrutinized using descriptive statistics and inferences drawn by use of correlation analysis. The investigation established that, the application of financial derivatives tools by quoted companies in Kenya is generally influenced by legal and regulatory framework, market environment, operational efficiency and the role of financial market intermediaries. Thus the research proposes that there is need for building upon existing financial derivatives tools so as to increase efficiency and effectiveness in their use in Kenya as new tools for financial risk management.

Mbungu (2013) carried out a study on factors influencing the development of derivatives markets in Kenya. Descriptive statistics such as percentages, means and frequencies were used to summarize the data. Results conclude that, government expenditure on financial infrastructure was insufficient for successful derivatives markets plus taxation was the main hindering factor in the development of derivatives markets. It was established that the support received from the central government in the expansion of derivatives markets was rated as fair whilst the awareness levels on derivatives tools by the investors was low. Derivatives cannot reduce the crucial control that the fiscal policy has over the levels of inflation. Conversely, high levels of foreign exchange reserves will to a great extent increase derivatives trading, thereby facilitating cross border capital flow. However it was determined that there was a probability of inadequate supply of derivatives instrument for hedging in the home market because the demand for derivatives was expected to be low. Derivatives dealing can improve market turnover of the underlying markets and consequently improve the GDP of the country. The trading in the derivatives markets is much influenced by local institutional and retail investors and also by overseas institutional and retail investors. The success of the derivatives markets in Kenya is mainly influenced by political environment, information on the derivatives, participant's position, financial infrastructure and foreign competition (Mbungu, 2013). It was noted that the support received from the central government in the development of derivatives markets could be rated as fair while the awareness levels about derivatives instruments by investors were rated as low.

Exchange rate movement in Kenya has been uneven with periods of rapid decline of the domestic currency, which may negatively affect the 
Kenyan economy (Ngugi, Njagi, \& Kimani, 2013). Although studies have been conducted on the exchange rate regimes and the repercussions for macroeconomic management in addition to managing foreign exchange risk (Abor, 2005), too little has been done on the study of a firms exposure to foreign exchange risk in Kenya.

\section{Summary of Literature Review and Research Gaps}

Though risk management is considered to involve a set of multifaceted indicators, considerable measurement errors due to the complex nature of the relations linking risk variables and performance indicators which make it hard to openly connect foreign exchange risk to profitability. Previous studies have provided a link between currency risk and firm performance Duangploy, Salini, Hanadan\& Wallace, 2008); (Ankrom, 2007) with modest and definite results. Others (Lee, 2010) have revealed that companies that have a strong currency risk management structure will have a higher profitability. There are also other studies (Broccardo, Mazzuca and Yaldiz, 2013; Allayannis and Ofek, 2000; Shaofang and Matej, 2014; Murungi, Murage and Wanjau, 2014; Runo, 2013; and Ngugi, Njagi and Kimani, 2013) which have presented the relationship between foreign exchange risk management strategies in other contexts. Most of the studies done focused on the various factors affecting derivatives or the effect of derivatives on various aspects in the finial market. However, no study that focuses on establishing the effect of hedging of financial risks either in the banking or non-banking sector has been carried out so far in Kenya. This is the research gap this study sought to fill.

\section{RESEARCH METHODOLOGY}

The study adopted a descriptive research design which generally describes the characteristics of a particular situation, event or case. It involves gathering data that describes events and then organizes, tabulates, depicts, and describes the data collection and often uses visual aids such as graphs and charts to help the reader in understanding data distribution. The population of the study constituted all 49 non-financial listed companies that were in operation as at $31^{\text {st }}$ December 2014 because that is the period over which we have full year audited financial reports. Data was collected from both primary and secondary sources. Primary data was collected using semistructured questionnaires sent to the 49 respondents. The questionnaire sought to collect both qualitative and quantitative data from open and close ended questions. Data was also collected from secondary sources as these are readily available from the financial reports and the Nairobi Securities Exchange (NSE). The study period was 2009-2013. For each firm, 
information on the type of risk and the hedging technique being used was collected.

Descriptive statistics was used to describe, organize and summarize data. Given the exploratory nature of the study, the data was further subjected to regression analysis. Theoretically, the exchange rate exposure of firms has potentially positive or negative impact on the profitability of the value of the firm. Accordingly, financial performance of the firm as measured by return on equity is the dependent variable while the exchange rate exposure categorized into strategies act as the independent variable in the proposed study. This theoretical relationship is captured in the following multiple regression model to enable the researcher achieve the stated objectives.

$$
Y=\beta_{0}+\beta_{1} X_{1}+\beta_{2} X_{2}++\beta_{3} X_{3}+\beta 4 X 4+\varepsilon
$$

Where $\quad \mathbf{Y}=$ Financial Performance (ROA)

$\mathbf{X}_{\mathbf{1}}$ =Financial Hedging strategies (SWAPs, Options, Futures, Forward contracts)

$\mathbf{X}_{\mathbf{2}}=$ Operational hedging strategies (Lead and Lag, Netting, Operating a foreign currency denominated account, Invoicing in domestic currency)

$\mathbf{X}_{3}=$ Interest rates (Lending rates)

$\mathbf{X}_{\mathbf{4}}=$ Inflation (CPI index)

$\boldsymbol{\varepsilon}=$ Error Term

$\boldsymbol{\beta}=$ Regression coefficients

In order to operationalize the hedging strategies, the study reviewed the proportion of amounts transacted through each of the strategy for each firm. These are always disclosed in financial statements as additional notes. The information in management's Discussion and Analysis highlights the hedging activities in the fiscal year. The information in financial instruments in notes of consolidated financial statement details hedging contracts throughout the year. A firm is considered to engage in hedging if it explicitly stated the derivative or hedging policy used in its financial statements.

\section{DATA ANALYSIS AND INTERPRETATION}

The study sought to establish the effect of foreign exchange rate risk management on financial performance of non -banking companies listed at the Nairobi Securities Exchange. The performance indicators that were addressed include profitability, sales revenue and Cash flow position and Liquidity. Findings are presented below.

\section{Profitability}

The study further sought to establish how effective the hedging strategies were on the company's profitability in the years 2009-2013. The 
respondents were required to indicate on a scale of 5 where 1-poor, 2-below average, 3-average, 4 -good and 5 excellent. The findings were as indicated below.

Table 1: Internal techniques

\begin{tabular}{ll}
\hline & Mean \\
\hline Leads and Lags & 3.967 \\
Netting & 4.235 \\
Invoicing in Foreign Currency & 3.897 \\
Money Market Hedges & 3.788 \\
\hline
\end{tabular}

Results on the table above indicate that, netting was effective on profitability with a mean of 4.235 , leads and lags with a mean of 3.967 and invoicing in foreign currency with a mean of 3.897.

Table 2: External techniques

\begin{tabular}{ll}
\hline & Mean \\
\hline Spots & 3.231 \\
Forwards & 3.027 \\
Futures & 3.593 \\
Options & 3.125 \\
Swaps & 2.956 \\
\hline
\end{tabular}

The above results indicate that, Futures were effective on profitability with a mean of 3.593 , spots with a mean of 3.231 while options had a mean of 3.125

\section{Sales Revenue}

The study further sought to establish how effective the hedging strategies were on the company's sales revenue in the years 2009-2014. The findings are as presented on the table below.

Table 3: Internal techniques

\begin{tabular}{ll}
\hline & Mean \\
\hline Leads and Lags & 3.096 \\
Netting & 3.120 \\
Invoicing in Foreign Currency & 3.452 \\
Money Market Hedges & 2.835 \\
\hline
\end{tabular}

Results from the table above indicate that, invoicing in foreign currency was effective with a mean of 3.452, netting with a mean of 3.120 and leads and lags with a mean of 3.096.

Table 4: External techniques

\begin{tabular}{ll}
\hline & Mean \\
\hline Spots & 2.563 \\
Forwards & 3.102 \\
Futures & 2.685 \\
Options & 2.864 \\
Swaps & 2.774 \\
\hline
\end{tabular}


Results from the table above indicate that, forwards was effective with a mean of 3.102, options with a mean of 2.864 and SWAPs had a mean of 2.774 .

\section{Cash flow position and Liquidity}

The study further sought to establish how effective the hedging strategies were on the company's cash flow position and liquidity in the years 2009-2013. The table below summarizes the results.

Table 5: Internal techniques

\begin{tabular}{ll}
\hline & Mean \\
\hline Leads and Lags & 4.122 \\
Netting & 3.954 \\
Invoicing in Foreign Currency & 3.562 \\
Money Market Hedges & 3.251 \\
\hline
\end{tabular}

Results from the table above indicate that, leads and lags were effective on cash flow position and liquidity with a mean of 4.122, netting had a mean of 3.954, invoicing in foreign currency had a mean of 3.562 while money market hedges had a mean of 3.251.

Table 6: External techniques

\begin{tabular}{ll}
\hline & Mean \\
\hline Spots & 3.201 \\
Forwards & 2.316 \\
Futures & 2.102 \\
Options & 2.567 \\
Swaps & 2.458 \\
\hline
\end{tabular}

Results on the table above indicate that, spots were effective on cash flow position and liquidity with a mean of 3.201, options had a mean of 2.567 while SWAPs had 2.458 .

\section{Regression Analysis}

The research conducted multiple regression analysis on the independent variables of the study over the period 2009 - 2013 and of performance of non-banking firms listed at the NSE.

Table 7: Model Summary

\begin{tabular}{llll}
\hline $\mathrm{R}$ & $\mathrm{R}^{2}$ & Adjusted $\mathrm{R}^{2}$ & Std. Error of the Estimate \\
\hline 0.869 & 0.755 & 0.701 & 0.1064 \\
\hline
\end{tabular}

Coefficient of determination explains the extent to which changes in the dependent variable can be explained by the change in the independent variables or the percentage of variation in the dependent variable (performance) that is explained by all the four independent variables (external hedging, internal hedging ,inflation, interest rates) 
The four independent variables that were studied, explain $75.5 \%$ of the variations in non-banking firms' performance as represented by the adjusted $\mathrm{R}^{2}$. This therefore means the four variables contribute to $75.5 \%$ of performance, while other factors not studied in this research contributes $24.5 \%$ of the variations.

Table 8: ANOVA

\begin{tabular}{llllll}
\hline Model & Sum of Squares & Df & Mean Square & F & Sig. \\
\hline Regression & 0.152 & 4 & .038 & 3.332 & .015 \\
Residual & 0.714 & 34 & .021 & & \\
\hline Total & 0.866 & 38 & & & \\
\hline
\end{tabular}

From the ANOVA statistics in the table above, the processed data, which are the population parameters, had a significance level of 0.015 which shows that the data is ideal for making a conclusion on the population's parameter. The F calculated at 5\% Level of significance was 3.332. Since F calculated is greater than the $\mathrm{F}$ critical (value $=2.6060$ ), this shows that the overall model was significant i.e. there is a significant relationship between hedging techniques and firms performance.

Table 9: Coefficients

\begin{tabular}{|l|l|l|l|l|l|}
\hline \multirow{2}{*}{ Model } & \multicolumn{2}{l|l|}{$\begin{array}{l}\text { Unstandardized } \\
\text { Coefficients }\end{array}$} & $\begin{array}{l}\text { Standardized } \\
\text { Coefficients }\end{array}$ & \multirow{2}{*}{ T ig. } \\
\cline { 2 - 4 } & $\mathrm{B}$ & Std. Error & Beta & & \\
\hline Constant & 0.564 & 0.162 & & 3.487 & 0.001 \\
\hline Internal hedging & 0.039 & 0.097 & 0.551 & 0.402 & 0.690 \\
\hline External hedging & 0.214 & 0.136 & 0.133 & 1.575 & 0.125 \\
\hline Inflation & 0.23 & 0.002 & 0.322 & 2.538 & 0.013 \\
\hline Interest Rate & 0.001 & 0.006 & 0.024 & 0.175 & 0.862 \\
\hline
\end{tabular}

Source: Research data

The established model for the study was:

$\mathrm{Y}=\mathbf{0 . 5 6 4}+\mathrm{0.551}_{1}+\mathrm{0.133}_{2}+\mathrm{0.322}_{3}+\mathrm{0.024}_{4}$

The regression equation above has established that taking all factors into account (internal hedging techniques, external hedging technique, inflation and interest rates) performance of non-financial firms would be 0.564 . The findings presented also show that internal hedging had the greatest effect on the firm performance $(\beta=0.551)$, Inflation $(\beta=0.322)$, External hedging $(\beta=0.133$ while interest rate $(\beta=0.024)$ had the least effect to the firms performance.

\section{Discussion of Results}

The study findings reveal that the independent variables (external hedging, internal hedging, inflation, interest rates) affected performance of non-financial firms. Internal hedging was found to have the greatest influence on performance of non-financial firms. These findings concur with 
Allayannis and Ofek (2000) who observed that forwards are the preferred hedging to improve performance. Also is in consistent with Riva (2006) that establish the use of derivatives increase bank efficiency.

Inflation was also found to have effect on the performance of nonfinancial firms. The findings is in consistent with Henschel and Kothari (2001) conducted an empirical study to determine the extent to which inflation reduce overall stock return volatility and Greek situation that the relationship between inflation level and banks profitability is remained to be debatable. The direction of the relationship is not clear (Vong \& Hoi, 2009). On interest rate it affected the performance of the non-financial firms to a small extent which concurs with Runo (2013) who examined the relationship between interest rate risk and profitability of oil companies listed in the Nairobi Securities Exchange Using correlation and regression analysis, research results indicated that the interest rate risk greatly influences the profits reported by these oil companies.

\section{CONCLUSION AND RECOMMENDATIONS Conclusion}

Based on the research findings the following conclusions were made. Firms are faced with foreign exchange risk and hence sought ways of managing these risks. The methods of managing this risks are both internal (netting, leads and lags, invoicing in foreign currency and money market hedges) and external techniques which includes forwards, spots, futures, options and SWAPs. The internal techniques are more preferred than the external techniques; this was attributed to the complexities that come along with external techniques. Hedging techniques affect firm's performance i.e. profitability, sales revenue and the cash flow and liquidity position of the firm. The internal techniques were more effective on the performance than the external techniques.

\section{Recommendations}

From the study findings, it is evident that firms need to manage foreign exchange risk. The companies should develop a robust foreign exchange risk management structure which evidently demonstrates its currency risk assessment procedure and implementation of currency risk management strategies. This should be regularly monitored and adjustments made where necessary. The companies should set up a risk management function within the organization tasked with the sole purpose of identifying, measuring, managing and monitoring foreign exchange risk.

Firms can adopt both internal and external risk management measures to evade variations linked to currency movements. The easiest and cheap option is to go for internal foreign exchange risk hedging like leading 
and lagging, netting and invoicing in foreign currency. External hedging techniques may also be adopted for example forward covers which should not be for extended periods of time because that too might be risky with the unpredictable nature of currency movements.

The decision to hedge against currency fluctuations is delicate and should be done in an informed manner as it can lead to substantial losses. The various aspects of firm's financial performance should be taken into consideration before adopting a particular technique to hedge as it would have effect on cash flow and liquidity, profitability or sales revenue. The three aspects are critical if a firm has to operate smoothly and remain competitive. If hedging is done in the correctly, it can help in cushioning the profits from unpredictable fluctuations in currencies and thus get more reliable financial results.

\section{References:}

1. Aabo, T. (2004). Exchange rate exposures and strategies of industrial companies: An empirical study. Thunderbird International Business Review. 8(1), 102-121

2. Abiero S. (2011). The effect of market risk management on company value among 60 firms listed at the NSE. Unpublished MBA Thesis, University of Nairobi

3. Abor, J. (2009).Managing foreign exchange risk among Ghanaian firms. Journal of Risk Finance 6 (4), 306-318.

4. Allayannis, G., \& Ofek, E. (2001). Exchange rate exposure, hedging, and the use of foreign currency derivatives. Journal of International Money \& Finance, 20(2), 273.

5. Al-Tamimi, H., \& Hassan, A. (2010).Factors Influencing Performance of the UAE Islamic and Conventional National Banks. . Department of Accounting, Finance and Economics, College of Business Administration, University of Sharjah

6. Ankrom, J. (2007). Corporate Financing and Investment Decisions When Firms Have Information that Investors do not have. Journal of Financial Economics 13, 187-221.

7. Athanasoglou, P.P., Sophocles, N.B., \& Matthaios, D.D. (2005) Bank-specific, industry-specific and macroeconomic determinants of bank profitability. Working paper 1(1), 3-4.

8. Armitage, J. C, Wold, P.J. \& Weissler, R., (2002).Adjustments for Changes in Exchange rates During an Advance Pricing Agreement Term unpublished Thesis.

9. BMO Capital Markets. (April 2012). Management policy: Objectives and Control. Journal of Foreign Exchange . 
10. Broccardo, E., Mazzuca, M., \& Yaldiz.E (2013).Uses and Motivations for Credit Derivatives: An Empirical Investigation into Italian Banks. DEM Discussion Papers

11. Dang, U. (2011).The CAMEL Rating System in Banking Supervision: a Case Study of Arcada University of Applied Sciences, International Business.

12. Diamond, D.W., \& Raghuram, A. (2000) A Theory of Bank Capital. The Journal of Finance 52(6), 12- 23

13. Duangploy, T. Salini, E. Hanadan, W \& Wallace, A. (2008). The management of strategic exchange risk: evidence from corporate practices. Accounting and Business Research, 12, 275-290.

14. Froot, K. A., Scharfstein, D. S., \& Stein, J. C. (1993). Risk Management: Coordinating Corporate investment and financing policy. The Journal of Finance, 58(5).

15. Giddy, I. H., \& Dufey, G. (2012). The management of foreign exchange risk. Journal of Finance, 5(2), 75-82.

16. Goosen, K., Jensen, R., \& Wells, R. (1999). Purpose and learning benefits of business simulations: A design and development perspective. Developments in Business Simulation \& Experiential Learning, 26, 133-145 .

17. Heremans, Dirk. (2007), Corporate Governance Issues for Banks: a Financial Stability Perspective, Working paper lee

18. Kirschner, L. (2009). The Power of a Dollar. . Risk Management (56(3), 76-80.

19. Madura, J. (2003). International Financial Management (7th Edition). Boston, MA: South-Western College Publishing.

20. Lee, C. (2010). Corporate diversification and firm performance. Journal of political economy

21. Mbungu, P.K (2013). An investigation into factors influencing the development of derivatives markets in Kenya. Unpublished MBA. Kenyatta University

22. Meyer, R. L. (2002). Track Record of Financial Institutions in Assisting the Poor in Asia.ADB Institute Research Paper, 49.

23. Mugera W.B (2013). The effect of foreign exchange risk management on the value of firms listed at The Nairobi Securities Exchange. Unpublished MBA Thesis, University of Nairobi

24. Murungi, C. M., Murage, K. \&Wanjau, K. (2014). Challenges facing nonfinancial firms in hedging financial risks using derivatives. International Journal of Social Sciences and Entrepreneurship, 1 (10), 361-374. 
25. Mwangi, M. K. (2001). Factors Hindering Financial Innovation in Kenya's Securities market: A study of firms listed at the NSE. Unpublished MBAProject. University of Nairobi

26. Namisi.R.N. (2002).Board of Directors Composition, Team Processes and Organizational performance of selected financial institutions in Uganda. Unpublished Research Dissertation submitted in partial fulfillment for the award of a degree at Makerere University

27. Ngugi, N. N., Njagi, G. M., \& Kimani, M. E. (2013). Factors influencing development of financial derivatives markets: a survey of listed companies in NSE.Unpublished MBAProject. University of Nairobi

28. Noor, J. A., \& Abdalla, A. I. (2014). European journal of business and management. The impact of financial risks on the firms' performance .

29. Runo F.N (2013). Relationship between foreign exchange risk and profitability of oil companies listed in the Nairobi Securities Exchange.Unpublished MBA Thesis. University of Nairobi

30. Rutagi . R (1997), Performance of parastatal Organizations in Uganda.Unpublished Research Dissertation submitted in partial fulfillment for the award of a degree at Makerere University

31. Shalishali, M. K. (2012). A Test of the International Fisher Effect in Selected Asian Countries.

32. Shaofang L. \& Matej, M (2014). The Use of Financial Derivatives and Risks of U.S. Bank Holding Companies

33. Shapiro, A.C., (1996), Multinational Financial Management, $\left(5^{\text {th }}\right.$ ed $)$ Hoboken, New Jersey: Wiley.

34. Vong, A., \& Hoi, S. (2009) Determinants of Bank Profitability in Macao. Faculty of Business Administration, University of Macau

35. Wade, M., \& Tomasevic, S. (2006). Retrieved November 5, 2014, from http://www.istheory.yorku.ca/contingencytheory.htm 